\title{
FAKTOR-FAKTOR YANG MEMPENGARUHI PENYUSUNAN ANGGARAN BELANJA BERBASIS KINERJA DI PEMERINTAH PROVINSI PAPUA BARAT
}

\author{
Nengsi Oktavia Makalew ${ }^{1}$ \\ Paulus K. Allo Layuk ${ }^{2}$ \\ Ida Ayu Purba Riani ${ }^{3}$
}

\begin{abstract}
This study aims to determine the effect of partially and simultaneously between Human Resources Competence, Organizational Commitment, and Appreciation on PerformanceBased Budgeting in the Regional Organizations of West Papua Province Government. The sample in this study were 96 employees. The analytical tool in this study is multiple linear regression using the SPSS Program.

The results showed that; 1) Partially independent variables (HR competencies and rewards influence the preparation of performance-based budgeting in the Regional Government of West Papua Province. 2). Together / simultaneously Human resource competency variables, organizational commitment, and rewards influence the preparation of performance-based budgeting in the Regional Government of West Papua Province. 3). The dominant variable influencing performance-based budgeting in the West Papua Provincial Government is the award.
\end{abstract}

Keywords: Competence, Commitment, Awards and Budget

\section{PENDAHULUAN}

Dalam proses penyusunan anggaran dikenal istilah penganggaran berbasis kinerja, yaitu metode penganggaran bagi manajemen untuk mengaitkan setiap biaya yang dituangkan dalam kegiatan-kegiatan agar sesuai dengan manfaat yang dihasilkan. Manfaat tersebut dideskripsikan sebagai seperangkat tujuan yang dituangkan dalam target kinerja pada setiap unit kerja (Iqsan, 2016). Sebagai tuntutan atas terselenggaranya anggaran berbasis kinerja, maka diperlukan juga reformasi keuangan dan anggaran agar pengalokasian anggaran lebih berorientasi pada kepentingan publik, Indrawati, 2017. Anggaran disusun berdasarkan pendekatan kinerja untuk mengatasi berbagai kelemahan yang ada dianggaran tradisional, hal ini dilakukan untuk meminimalka kelemahan yang disebabkan oleh tidak adanya tolak ukur yang dapat digunakan untuk mengukur kinerja

\footnotetext{
${ }^{1}$ Alumni Magister Keuangan Daerah Universitas Cenderawasih

2 Dosen Magister Keuangan Daerah Universitas Cenderawasih

${ }^{3}$ Dosen Magister Keuangan Daerah Universitas Cenderawasih
} 
dalam pencapaian tujuan dan sasaran pelayanan publik. Dalam era reformasi birokrasi pemerintah, OPD diharapkan dapat membantu mewujudkan tata kepemerintahan yang baik (good public governance), melalui pencapaian kinerja yang efisien, efektif dan bebas dari korupsi, kolusi dan nepotisme.

Menghadapi implementasi perubahan sistem penganggaran, dibutuhkan kualitas sumber daya manusia yang mampu menghadapi dan siap mencari solusi yang memadai. Menurut Nugroho (2007) visi dan misi serta tujuan organisasi dapat terwujud apabila ditopang oleh sumber daya manusia sebagai pilar penyangga utama sekaligus penggerak roda organisasi. Biro Keuangan Provinsi Papua Barat sebagai instansi pemerintah diharapkan memiliki kualitas pelayanan publik yang profesional dan berintegritas serta bertanggungjawab. Keberhasilan pelayanan pengelolaan keuangan kepada Pemerintah Pusat maupun masyarakat sangat bergantung pada kinerja dan pemahaman setiap pegawai.

Salah satu perubahan mendasar adalah pengelolaan kuangan daerah. Organisasi sektor publik umumnya bergantung pada alokasi anggaran pemerintah untuk pendanaan dalam melaksanakan pelayanan publik Campbell (2009). Perimbangan keuangan antara pemerintah pusat dan pemerintah daerah mengamanatkan bahwa keuangan daerah harus dikelola dengan tertib, taat pada perundang-undangan, efisien, ekonomis, efektif, transparan, dan bertanggungjawab dengan memperhatikan keadilan, kepatuhan dan manfaat untuk masyarakat. Hal tersebut mengharuskan pemerintah untuk menempatkan sumber daya manusia yang berkompeten dan memahami aturan penyusunan anggaran. Kompetensi yang dimiliki sumber daya manusia mencakup keterampilan, pengetahuan, pelatihan dan kemampuan yang terstandar.

Anggaran Pendapatan dan Belanja Daerah adalah suatu bentuk konkrit rencana kerja keuangan daerah yang komprehensif yang mengaitkan penerimaan dan pengeluaran pemerintah daerah yang dinyatakan dalam bentuk uang untuk mencapai tujuan atau target yang direncanakan dalam jangka waktu tertentu dalam satu tahun anggaran. Dalam Undang-Undang Nomor 33 Tahun 2004 Pasal 1 ayat 17 menyebutkan bahwa anggaran pendapatan dan belanja daerah, selanjutnya disebut APBD adalah rencana 
keuangan tahunan Pemerintahan Daerah yang dibahas dan disetujui bersama oleh Pemerintah Daerah dan Dewan Perwakilan Rakyat Daerah, dan ditetapkan dengan Peraturan Daerah. Penyusunan APBD berbasis kinerja adalah penyusunan anggaran pendapatan dan belanja daerah yang berbasis kinerja sebagai rencana keuangan tahunan daerah dari suatu sistem anggaran yang mengutamakan upaya pencapaian hasil kerja atau keluaran dari perencanaan alokasi biaya.

Satuan Kerja Perangkat Daerah atau Organisasi Perangkat Daerah di lingkungan Pemerintah Provinsi Papua Barat dalam menyusun anggaran belanja belum sepenuhnya berdasarkan penganggaran berbasis kinerja, dimana beberapa komponen penting sebagai dasar penilaian terhadap keberhasilan penganggaran berbasis kinerja belum sepenuhnya diimplementasikan dengan benar. Tujuan dari penelitian ini adalah untuk mengetahui pengaruh faktor kompetensi sumber daya manusia, komitmen dari seluruh komponen organisasi, dan penghargaan terhadap penyusunan anggaran berbasis kinerja. Penelitian yang akan dilakukan ini merupakan replikasi dari penelitian-penelitian yang telah dilakukan sebelumnya dengan menguji kembali pada pengaturan dan responden yang berbeda. Penelitian ini mengambil subyek organisasi sektor publik atau organisasi pemerintah. Selain itu, terdapat beberapa faktor yang mempengaruhi penyusunan anggaran belanja pemerintah daerah, maka penelitian ini dilakukan untuk mendeskriptifkan pemahaman pegawai dalam Organisasi Perangkat Daerah terkait penyusunan dan perencanaan anggaran belanja.

\section{LANDASAN TEORI DAN PENGEMBANGAN HIPOTESIS}

\section{Landasan Teori}

\section{Anggaran Berbasis Kinerja}

Anggaran berbasis kinerja merupakan metode penganggaran bagi manajemen untuk mengaitkan setiap biaya yang dituangkan dalam kegiatan-kegiatan dengan manfaat yang dihasilkan. Manfaat tersebut dideskripsikan pada seperangkat tujuan dan dituangkan dalam target kinerja pada setiap unit kerja (Hariyadi, 2015). Peraturan Pemerintah Nomor 58 
Tahun 2005 tentang pengelolaan keuangan daerah dijelaskan bahwa penerapan anggaran berbasis kinerja mengandung makna "dalam meningkatkan kesejahteraan hidupnya setiap penyelenggaraan Negara berkewajiban untuk bertanggung jawab atas hasil proses dan penggunaan sumber dayanya, agar setiap program dan kegiatan pemerintahan yang didanai dengan dana publik dapat dinikmati dan dirasakan manfaatnya oleh rakyat.

Penganggaran berbasis kinerja merupakan metode penganggaran bagi manajemen untuk mengaitkan setiap pendanaan yang dituangkan dalam kegiatankegiatan dengan keluaran dan hasil yang diharapkan, termasuk efisiensi dalam pencapaian hasil dari keluaran tersebut. Keluaran dan hasil tersebut dituangkan dalam target kinerja pada setiap unit kerja. Sedangkan bagaimana tujuan itu dicapai, dituangkan dalam program, diikuti dengan pembiayaan pada setiap tingkat pencapaian tujuan. Dalam pedoman penyusunan anggaran berbasis kinerja, BPKP (2010), menyatakan bahwa program pada anggaran berbasis kinerja didefinisikan sebagai instrument kebijakan yang berisi satu atau lebih kegiatan yang akan dilaksanakan oleh instansi pemerintah/lembaga untuk mencapai sasaran dan tujuan, serta memperoleh alokasi anggaran atau kegiatan masyarakat yang dikoordinasikan oleh instansi pemerintah. Aktivitas tersebut disusun sebagai cara untuk mencapai kinerja tahunan.

\section{Kompetensi Sumber Daya Manusia}

Sumber daya manusia (SDM) berkualitas tinggi adalah SDM yang mampu menciptakan bukan saja nilai komparatif, tetapi juga nilai kompetitif-generatifinovatif dengan menggunakan energy tertinggi seperti intelligence, creativity, dan imagination; tidak lagi semata-mata menggunakan energy kasar seperti bahan mentah, lahan, air, tenaga otot, dan sebagainya (Ndraha, 2005). Dalam mengelola SDM, diperlukan sistem pengendalian manajemen agar tujuan organisasi tercapai. Sistem pengendalian manajemen suatu organisasi dirancang untuk mempengaruhi orang-orang di dalam organisasi tersebut agar berperilaku sesuai dengan tujuan organisasi.

Manfaat Penggunaan Kompetensi Sumber Daya Manusia Sutrisno (2012) mengemukakan bahwa penggunaan konsep kompetensi sumber daya manusia didalam 
suatu perusahaan digunakan atas berbagai alasan, yaitu a) Memperjelas standar kerja dan harapan yang ingin dicapai; b) Alat seleksi karyawan; c) Memaksimalkan produktivitas; d) Dasar untuk pengembangan sistem remunerasi; e) Memudahkan adaptasi terhadap perubahan; f) Menyelaraskan perilaku kerja dengan nilai-nilai organisasi.

Faktor-Faktor Yang Mempengaruhi Kompetensi Sumber Daya Manusia menurut Wibowo (2013) adalah bahwa terdapat beberapa faktor yang dapat memengaruhi kecakapan kompetensi seseorang, yaitu sebagai berikut a) Keyakinan dan Nilai-nilai; b) Keterampilan; c) Pengalaman Keahlian dari banyak kompetensi; d) Karekteristik; e) Kepribadian; f) Motivasi; g) Isu emosional; h) Kemampuan intelektual; i) Budaya organisasi.

Menurut Asikin (2013), terdapat beberapa indikator dalam menentukan variabel Personil/Individual (SDM) yaitu a) Kesesuaian Pendidikan dengan pekerjaan; b) Pengetahuan atas apa yang dikerjakan; c) Keberanian mengambil tindakan atas apa yang dikerjakan; d) Keikutsertaan dalam pendidikan/pelatihan; e) Memiliki hak akses terhadap apa yang dikerjakan; f) Ketersediaan SDM yang sesuai dengan bidang pekerjaan.

\section{Komitmen Organisasi}

Konsep tentang komitmen karyawan terhadap organisasi ini (disebut pula dengan komitmen kerja), yang mendapat perhatian dari manajer maupun ahli perilaku organisasi, berkembang dari studi awal mengenai loyalitas karyawan yang diharapkan ada pada setiap karyawan. Komitmen kerja atau komitmen organisasi merupakan suatu kondisi yang dirasakan oleh karyawan yang dapat menimbulkan perilaku positif yang kuat terhadap organisasi kerja yang dimilikinya. Menurut Djati (2004) suatu bentuk komitmen kerja yang muncul bukan hanya bersifat loyalitas yang pasif, tetapi juga melibatkan hubungan yang aktif dengan organisasi kerja yang memiliki tujuan memberikan segala usaha demi keberhasilan organisasi kerja yang bersangkutan. Premeaux \& Mondy (1993) mendefinisikan komitmen kerja sebagai kekuatan relatif dari identifikasi individu dan keterlibatannya dengan organisasi kerja.

Menurut Sopiah (2008) terdapat tiga bentuk komitmen organisasi yaitu a) Komitmen berkesinambungan (continuance commitment), yaitu komitmen yang berkaitan dengan 
dedikasi anggota dalam melanjutkan kelangsungan hidup organisasi dan menghasilkan orang yang mau berkorban dan berinvestasi pada organisasi; b) Komitmen terpadu (cohesion commitment), yaitu komitmen anggota terhadap organisasi sebagai akibat adanya hubungan sosial dengan anggota lain didalam organisasi. Hal ini terjadi karena kepercayaan karyawan pada normanorma yang dianut organisasi merupakan norma-norma yang bermanfaat; c) Komitmenn terkontrol (control commitment), yaitu komitmen anggota pada norma organisasi yang memberikan perilaku ke arah yang diinginkannya. Sebab normanorma tersebut mampu dan sesuai dalam memberikan sumbangan terhadap perilaku yang diinginkannya. Faktor-faktor yang mempengaruhi komitmen organisasi menurut Yusuf (2015) adalah a) Kemampuan pimpinan dan lingkungan organisasi/perusahaan dalam menumbuhkan sikap dan perilaku profesional dalam menyelesaikan tugas/tanggung jawab organisasi; b) Peran konflik dan stress; c) Pengalaman kerja, masa kerja yang lama menunjukkan pengalaman yang lebih dari seseorang dengan rekan kerja yang lain; d) Faktor budaya. Faktor Budaya organisasi yang baik tentunya akan mempengaruhi kualitas pelayanan publik yang baik pula.

Dimensi komitmen organisasi yang dijadikan indikator dalam penelitian ini adalah 3 (tiga) hal yang dikemukakan oleh Robbin (2008), yaitu a) Komitmen afektif (affective commitment): adanya ikatan emsosional karyawan, identifikasi, dan keterlibatan dalam organisasi karena keinginan dari diri sendiri; b) Komitmen berkelanjutan (continuance commitment): komitmen didasarkan atas kebutuhan rasional yang terbentuk atas pertimbangkan untung dan rugi yang didapatkan karyawan, sehingga karyawan harus bertahan dan berkorban untuk menetap pada suatu organisasi; c) Komitmen normatif (normative commitment): komitmen yang didasarkan pada norma yang ada dalam diri karyawan berkaitan keyakinan individu akan tanggung jawab terhadap organisasi, sehingga karyawan harus loyal atau setia kepada organisasi.

\section{Penghargaan}

Penghargaan dapat diartikan sebagai sebuah bentuk apresiasi kepada suatu prestasi tertentu yang diberikan, baik oleh dan dari perorangan ataupun suatu lembaga yang 
biasanya dalam bentuk material atau ucapan. Penghargaan biasa diberikan dalam bentuk material atau non material yang oleh pihak pimpinan/organisasi perusahaan kepada karyawan bertujuan agar memotivasi mereka bekerja lebih keras dan berprestasi dalam mencapai tujuan-tujuan perusahaan atau organisasi.

Sistem pemberian penghargaan atau imbalan yang baik adalah sistem yang mampu menjamin kepuasan para pegawai perusahaan/organisasi yang pada gilirannya memungkinkan perusahaan memperoleh, memelihara, dan mempekerjakan sejumlah orang yang dengan berbagai sikap dan perilaku positif bekerja dengan produktif bagi kepentingan perusahaan. Para pegawai harus mendapat perhatian dalam arti bahwa penghargaan yang diterima atas jasa yang diberikan kepada perusahaan harus memungkinkannya mempertahankan harkat dan martabat sebagai insan yang terhormat. Oleh sebab itu, memberikan berbagai macam penghargaan untuk pegawai yang berprestasi dan memiliki loyalitas tinggi terhadap perusahaan.

Menurut Simamora, Alvarez, \& Yalkowsky (2001), penghargaan atau kompensasi meliputi kembalian-kembalian finansial dan jasa terwujud dan tunjangan-tunjangan yang diterima karyawan sebagai bagian dari hubungan kepegawaian. Kompensasi merupakan apa yang diterima oleh para karyawan sebagai ganti kontribusi mereka kepada organisasi. Sebagai suatu respon/pemberian penghargaan terhadap suatu capain kinerja tertentu yang dimaksudkan sebagai rangsangan/motivasi agar terus berprestasi. Indikator penghargaan menurut Muhandri \& Kadarisman (2012) terdiri atas: Upah, Gaji, Bonus/intensif, Tunjangan dan Penghargaan interpersonal secara psikologis/sosial.

\section{Pengembangan Hipotesis}

\section{Kompetensi Sumber Daya Manusia dan Penyusunan Anggaran Berbasis Kinerja}

Penelitian yang dilakukan oleh Muhammad lqbal (2018), Terdapat pengaruh positif signifikan kompetensi sumber daya manusia (SDM) terhadap penyerapan anggaran. Hal ini bermakna apabila aparatur pemerintah pengelola anggaran didukung oleh kompetensi yang tinggi, maka akan memengaruhi perilaku kerja paparatur pemerintah yang kemudian akan memengaruhi kinerjanya serta kinerja organisasi secara umum. Hasil penelitiannya 
menemukan bahwa salah satu faktor yang mempengaruhi penerapan anggaran berbasis kinerja adalah kompetensi sumber daya manusia (SDM). Dengan demikian, kualitas sumber daya manusia memiliki peranan penting dalam penyusunan rencana APBD berbasis kinerja.

Sumber daya manusia berhubungan erat dengan kemampuan penyusunan anggaran terhadap detail tugas dan tanggung jawab pada tahap: mempersiapkan deskripsi pekerjaan; jumlah dan kualifikasi staf; dan terpenuhinya kebutuhan perekrutan. Faktor kunci keberhasilan dalam penyusunan anggaran adalah staf yang berpengalaman dan mempunyai motivasi. Staf juga harus dilengkapi dengan uraian tugas yang tepat.

\section{Komitmen Organisasi dan Penyusunan Anggaran Berbasis Kinerja}

Semakin fleksibel organisasi yang menekankan pada partisipasi angota dapat meningkatkan komitmen organisasi secara positif serta cukup kuat. Kusumaputri (2015) mengatakan karakteristik individu menjadi faktor yang tidak kalah penting dengan faktorfaktor yang lainnya, karakter individu sendiri merupakan hal yang melekat dalam individu. Dalam kerangka perilaku organisasi terdapat sejumlah sikap yang berkaitan dengan pekerjaan. Kebanyakan riset dalam ilmu perilaku organisasi memperhatikan ketiga sikap yang meliputi: kepuasan kerja, keterlibatan kerja, dan komitmen organisasi. Komitmen organisasi secara umum dipahami sebagai ikatan kejiwaan individu terhadap organisasi termasuk keterlibatan kerja, kesetiaan dan perasaan percaya pada nilai-nilai organisasi.

Komitmen secara sederhana sebagai ikatan psikologis seseorang terhadap suatu organisasi. Ikatan ini tercipta karena adanya kepercayaan (belief) dari individu yang bersangkutan bahwa komitmen merupakan kewajiban moralnya terhadap perusahaan tempat mereka bekerja. Kepercayaan tersebut melekat pada individu dan ikatan psikologis juga tercipta bilamana nilai-nilai dan norma-norma yang dianut oleh seseorang sesuai dengan visi, misi dan kebijakan dan gaya pengelolaan perusahaan tempat kerjanya.

Pendekatan membangun Komitmen kerja karyawan atau organisasi menurut Yusuf dkk (2007) adalah komitmen pegawai perlu dibangun sejak mulai rekrutmen dan seleksi. Perusahaan merekrut mereka yang memiliki kepercayaan bahwa komitmen merupakan kewajiban moral terhadap perusahaan tempat mereka bekerja. Dalam proses perjalanan 
perusahaan selalu mensosialisasi visi, misi, kebijakan dan gaya pengelolaan keuangan serta mendorong pegawai untuk menyesuaikan. Dengan resiko bila tidak ada kesuaian maka akan mengundurkan diri dari perusahaan.

\section{Penghargaan dan Penyusunan Anggaran Berbasis Kinerja}

Penghargaan menurut Irmayanti (2013) merupakan imbalan intrinsik atau imbalan yang berasal dari pekerjaan itu sendiri, dan biasanya berupa rasa penyelesaian, prestasi, otonomi, dan pertumbuhan. Secara lebih terperinci hal tersebut diperlukan untuk mengembangkan kemampuan untuk memulai atau menyelesaikan suatu proyek pekerjaan. Sembiring , 2009 mengatakan penghargaan yang jelas berpengaruh signifikan terhadap APBD berbasis kinerja. Selanjutnya, bila dihubungangkan dengan penerapan anggaran berbasis kinerja, berpengaruh signifkan terhadap anggaran berbasis kinerja.

Berdasarkan uraian dalam fenomena dan research gap diatas, maka tujuan penelitian ini adalah untuk mengetahui dan menganalisis pengaruh Kompetensi Sumber Daya Manusia, Komitmen Organisasi, Sistem Administrasi Dan Penghargaan Terhadap Penyusunan Anggaran Belanja Berbasis Kinerja dan untuk mengetahui dan menganalisis variabel yang dominan berpengaruh terhadap penyusunan anggaran berbasis kinerja.

Dari hasil penelitian-penelitian terdahulu diketahui bahwa rata-rata penyusunan anggaran berbasis kinerja kurang maksimal, hal tersebut dapat dilihat berdasarkan indikasi adanya pengaruh yang positif dan signifikan dari variabel-variabel yang dikemukakan di atas terhadap penerapan anggaran berbasis kinerja. Oleh sebab itu, beberapa variabel seperti peranan pimpinan, personil/individual (SDM), sistem administrasi, dan pemberian penghargaan menjadi kewajiban yang harus diperhatikan oleh organisasi pemerintah dalam meningkatkan pemahaman OPD terkait pengimplementasian anggaran berbasis kinerja. Secara keseluruhan, pegawai (OPD) diharapkan memiliki kemamampuan dan kecakapan dalam menangkap berbagai dorongan yang diberikan oleh organisasi sehingga dapat memacu motivasi kerjanya disamping juga meningkatkan kemampuan kinerjanya dalam menyusun APBD berbasis kinerja. 
Berdasarkan uraian temuan dari penelitian-penelitian tersebut diatas, serta uraian dalam fenomena dan research gap, dapat dikemukakan bahwa faktor Personal/individual (SDM), komitmen organisasi dan Pemberian penghargaan memiliki korelasi yang erat dengan penerapan Anggaran berbasis kinerja.

\section{METODOLOGI PENELITIAN}

\section{Lokasi Penelitian}

Penelitian ini dilakukan pada semua karyawan atau pegawai yang berstatus pegawai negeri sipil (PNS) dan bekerja pada bagian keuangan pada seluruh OPD/SKPD dilingkungan Pemerintah Provinsi Papua Barat.

\section{Populasi dan Sampel Penelitian}

Populasi dalam penelitian ini adalah karyawan atau pegawai yang bekerja pada bagian keuangan pada seluruh OPD/SKPD dilingkungan Pemerintah Provinsi Papua Barat. Jumlah pegawai bagian keuangan seluruh OPD/SKPD dilingkungan Pemerintah Provinsi Papua Barat yang menjadi populasi dalam penelitian ini adalah sebanyak 96 orang. Dengan teknik sampling yaitu Stratified Purposive sampling. Dikarenakan jumlah pegawai atau keseluruhan populasi kurang dari 100 yaitu 96 orang, maka dalam penelitian ini semua populasi dijadikan subjek penelitian. Dengan demikian tehnik pengambilan sampel yang digunakan dalam penelitian ini adalah tehnik sampling jenuh atau sensus Sugiyono, 2004.

\section{Jenis Penelitian dan Sumber Data}

Jenis penelitian adalah eksplanatori dengan sumber data penelitian dikelompokan menjadi dua, yaitu data primer dan data sekunder.

\section{Definisi Operasional Variabel}

Variabel Bebas (Independent Variable) merupakan variabel yang menjadi penyebab adanya variabel terikat, yang terdiri dari:

a. Variabel Kompetensi Sumber Daya Manusia (X1), didefinisikan sebagai karyawan/pegawai yang bersedia dengan siap, memiliki keinginan kuat untuk mampu 
berkontribusi dalam suatu tujuan organisasi, dengan indikator sebagai berikut: Kesesuaian Pendidikan dengan pekerjaan, pengetahuan atas apa yang dikerjakan, keberanian mengambil tindakan atas apa yang dikerjakan, keikutsertaan dalam pendidikan atau pelatihan, memiliki hak akses terhadap apa yang dikerjakan dan ketersediaan SDM yang sesuai denganidang pekerjaan.

b. Variabel Komitmen Organisasi (X2), merupakan kekuatan yang bersifat relatif dari individu dalam mengidentifikasikan keterlibatan dirinya ke dalam bagian organisasi, mengenal pasti tujuan dan nilai organisasi, keinginan menjadi milik organisasi dan kesanggupan untuk berusaha menjadi milik organisasi. Adanya kesamaan nilai dan tujuan antara individu dan perusahaan, dengan indikator sebagai berikut: Komitmen afektif: adanya kemauan karyawan untuk mengusahakan agar tercapainya kepentingan organisasi; Komitmen berkelanjutan yaitu adanya kesetiaan karyawan untuk mempertahankan keanggotaannya menjadi bagian dari organisasi, dan; Komitmen normatif yaitu adanya kebanggaan karyawan menjadi bagian dari organisasi selama hidupnya.

c. Variabel Penghargaan (X3) merupakan suatu respon/pemberian penghargaan terhadap suatu capain kinerja tertentu yang dimaksudkan sebagai rangsangan/motivasi agar terus berprestasi. Indikator penghargaan adalah upah, tunjangan, bonus/intensif, kesejaterahan, pengembangan karir, dan penghargaan secara psikologis/sosial.

Variabel Terikat (Dependent Variabel), merupakan variabel yang muncul sebagai akibat dari adanya variabel bebas, yaitu $\mathrm{Y}$ (Penyusunan Anggaran Berbasis Kinerja). Anggaran Berbasis Kinerja $(Y)$ adalah suatu sistem anggaran yang mengutamakan upaya pencapaian hasil atau output dari perencanaan biaya. Pengukuran Anggaran Berbasis Kinerja berdasarkan indikator sebagai berikut: Kontribusi dalam penyusunan anggaran, keterlibatan dalam penyusunan anggaran, alasan melakukan revisi angaran, usulan kepada atasan, dan penyelesaian akhir dan meminta pendapat atasan.

Untuk mengukur variabel-variabel yang akan diteliti melalui tanggapan responden digunakan skala likert, dalam penelitian ini masing-masing jawaban pertanyaan dalam 
kuesioner diberi bobot sebagai berikut: Sangat tidak setuju diberi bobot 1; Tidak setuju diberi bobot 2; Cukup setuju diberi bobot 3; Setuju diberi bobot 4; dan Sangat setuju diberi bobot 5. Metode Analisis Data

Metode Analisis Data yang digunakan dalam penelitian ini terdiri dari Analisis Deskriptif dan Analisis Kuantitatif. Analisis deskriptif yaitu suatu teknik untuk mengungkapkan dan memaparkan pendapat dari responden berdasarkan jawaban dari instrumen penelitian yang telah diajukan oleh peneliti. Dari data yang telah terkumpul kemudian dilakukan analisis data secara deskriptif yaitu dengan cara memaparkan secara objektif dan sistematis situasi yang ada dilapangan. Analisa deskriptif digunakan untuk mengedit dan menyajikan data serta memberikan penjelasan-penjelasan atas hasil-hasil temuan dalam penelitian dan hasil analisa kuantitatif dengan statistik. Analisa kuantitatif yaitu analisa dalam bentuk angka-angka berupa jumlah jawaban responden yang dikuantitatifkan dengan menggunakan skala Likert, kemudian mentabulasi dan menganalisis dengan analisis statistik dengan bantuan Program Statistical Product and Service Solutions (SPSS) 21 for windows.

\section{HASIL PENELITIAN DAN PEMBAHASAN}

\section{Analisis Data}

\section{Uji Instrumen Penelitian}

Pengujian instrumen terhadap indikator-indikator dari masing-masing variabel (dependen dan independen) yang digunakan dalam penelitian ini dilakukan untuk dapat mengetahui tingkat kevalidan dan keandalan indikator-indikator tersebut sebagai alat ukur variabel.

Hasil pengujian Validitas dan Reliabilitas dari masing-masing variabel penelitian yang meliputi Kompetensi (X1), Komitmen Organisasi (X2), Penghargaan (X3) dan Anggaran Berbasis kinerja (Y) dapat dilihat pada tabel berikut. 
Tabel 1.1 Uji Validitas dan Reliabilitas Variabel Penelitian: Kompetensi (X1), Komitmen Organisasi (X2), Penghargaan (X3) dan Anggaran Berbasis Kinerja (Y)

\begin{tabular}{|c|c|c|c|c|}
\hline No. & \multicolumn{3}{|c|}{ Uji Validitas } & Reabilitas \\
\hline & Nilai $r$ & Sig & Keterangan & Cronbach's Alpha \\
\hline \multicolumn{4}{|c|}{ Kompetensi (X1) } & \multirow{7}{*}{ 0,688 (Reliable) } \\
\hline$\overline{X 1.1}$ & 0,433 & 0,000 & Valid & \\
\hline $\mathrm{X} 1.2$ & 0,306 & 0,000 & Valid & \\
\hline $\mathrm{X} 1.3$ & 0,573 & 0,000 & Valid & \\
\hline $\mathrm{X} 1.4$ & 0,485 & 0,000 & Valid & \\
\hline $\mathrm{X} 1.5$ & 0,369 & 0,000 & Valid & \\
\hline$\overline{X 1.6}$ & 0,378 & 0,000 & Valid & \\
\hline \multicolumn{4}{|c|}{ Komitmen Organisasi (X2) } & \multirow{4}{*}{ 0,613 (Reliable) } \\
\hline $\bar{X} 2.1$ & 0,335 & 0,000 & Valid & \\
\hline $\mathrm{X} 2.2$ & 0,471 & 0,000 & Valid & \\
\hline $\mathrm{X} 2.3$ & 0,463 & 0,000 & Valid & \\
\hline \multicolumn{4}{|c|}{ Penghargaan (X3) } & \multirow{6}{*}{ 0,728 (Reliable) } \\
\hline $\mathrm{X} 3.1$ & 0,525 & 0,000 & Valid & \\
\hline $\mathrm{X} 3.2$ & 0,355 & 0,000 & Valid & \\
\hline X3.3 & 0,654 & 0,000 & Valid & \\
\hline X3.4 & 0,379 & 0,000 & Valid & \\
\hline X3.5 & 0,541 & 0,000 & Valid & \\
\hline \multicolumn{4}{|c|}{ Anggaran Berbasis Kinerja (Y) } & \multirow{6}{*}{ 0,782 (Reliable) } \\
\hline $\mathrm{Y} 1.1$ & 0,722 & 0,000 & Valid & \\
\hline $\mathrm{Y} 1.2$ & 0,736 & 0,000 & Valid & \\
\hline Y1.3 & 0,592 & 0,000 & Valid & \\
\hline Y1.4 & 0,704 & 0,000 & Valid & \\
\hline Y1.5 & 0,412 & 0,000 & Valid & \\
\hline
\end{tabular}

Sumber: Lampiran, diolah 2019

Hasil analisas validitas dan reabilitas tehadap variabel Kompetensi (X1), Komitmen Organisasi (X2), Penghargaan (X3) dan Anggaran Berbasisi Kinerja (Y), menunjukan bahwa nilai $r$ untuk kesemua item pertanyaan dari masing-masing indikator nilainya lebih besar dari 0,3 dan Nilai Cronbach's Alpha masing-masing variabel lebih besar dari 0,6. Dari hasil uji validitas dan reabilitas tersebut dapat dijelaskan bahwa intrusmen penelitian untuk keempat variabel dalam penelitian ini adalah valid dan reliable, sehingga dapat digunakan sebagai intrumen atau alat ukur dalam penelitian ini.

\section{Uji Model Regresi}

a. Uji Multikolinieritas. Pengujian multikolinearitas bertujuan untuk mengetahui ada tidaknya korelasi yang signifikan yang mendekati sempurna antar variabel independen. Jika antar 
sesama variabel independen terdapat korelasi yang signifikan, maka pada model regresi linear tersebut terdapat gejala multikolinearitas. Model regresi yang baik adalah tidak terdapat multikolinearitas. Tabel berikut ini menyajikan hasil pengujian multikoleniaritas:

Tabel 1.2 Nilai Tolerance dan VIF

Nilai Tolerance dan VIF

\begin{tabular}{|l|r|r|}
\hline \multicolumn{1}{|c|}{ Variabel } & \multicolumn{2}{|c|}{ Collinearity Statistics } \\
\hline & Tolerance & \multicolumn{1}{c|}{ VIF } \\
\hline & & \\
Kompetensi & 0,874 & 1,181 \\
Komitmen Organisasi & 0,857 & 1,167 \\
Penghargaan & 0,813 & 1,230 \\
& & \\
\hline
\end{tabular}

Sumber: Lampiran, diolah, 2019

Berdasarkan hasil pengujian multikolinieritas diperoleh hasil perhitungan nilai toleransi untuk ketiga variabel bebas yaitu Kompetensi, Komitmen Organisasi, dan Penghargaan lebih besar dari satu $(>0,1)$. Sehingga dapat disimpulkan bahwa tidak terdapat multikolinieritas antara variabel independen dalam model regresi pada penelitian ini.

b. Uji Normalitas. Pengujian normalitas bertujuan untuk menguji apakah variabel terikat dan variabel bebas dalam model regresi mempunyai distribusi normal atau tidak. Model regresi yang baik adalah yang memiliki distribusi normal atau mendekati normal.

Tabel 1.3 One-Sample Kolmogorov-Smirnov Test

\begin{tabular}{|ll|r|}
\hline & & $\begin{array}{c}\text { Unstandardized } \\
\text { Residual }\end{array}$ \\
\hline$N$ & Mean & 96 \\
Normal Parameters & a,b & .0000000 \\
Most Extreme & Std. Deviation & 1.81731344 \\
Differences & Absolute & .074 \\
& Positive & .063 \\
Kolmogorov-Smirnov Z & Negative & -.074 \\
Asymp. Sig. (2-tailed) & & .728 \\
Sumb: Lampian, diolah, 2019 & .664 \\
\hline
\end{tabular}

Sumber: Lampiran, diolah, 2019

Berdasarkan hasil yang ditampilakan pada Tabel di atas, terlihat bahwa nilai signifikansi (Asymp. Sig. (2-tailed) adalah sebesar 0.664, sehingga dapat dinyatakan bahwa data yang 
berasal darai model regresi yang digunakan terdistribusi normal atau memenuhi asumsi normalitas.

c. Uji Autokorelasi. Untuk mendeteksi autokorelasi dapat dilihat pada tabel critical values of the Durbin-Watson test statistic.

Tabel 1.4 Uji Autokorelasi

Model Summary ${ }^{b}$

\begin{tabular}{|l|l|r|r|r|r|}
\hline Model & $\mathrm{R}$ & $\begin{array}{c}\mathrm{R} \\
\text { Square }\end{array}$ & $\begin{array}{c}\text { Adjusted R } \\
\text { Square }\end{array}$ & $\begin{array}{c}\text { Std. Error of } \\
\text { the Estimate }\end{array}$ & $\begin{array}{c}\text { Durbin- } \\
\text { Watson }\end{array}$ \\
\hline 1 & $.427^{\text {a }}$ & .183 & .156 & 1.84671 & 1.844 \\
& & & & & \\
& & & & & \\
\end{tabular}

a. Predictors: (Constant), Penghargaan, Komitmen, Kompetensi

b. Dependent Variable: Anggaran

Sumber : Lampiran, diolah, 2019

Gambar Daerah Kritis Uji Durbin-Watson

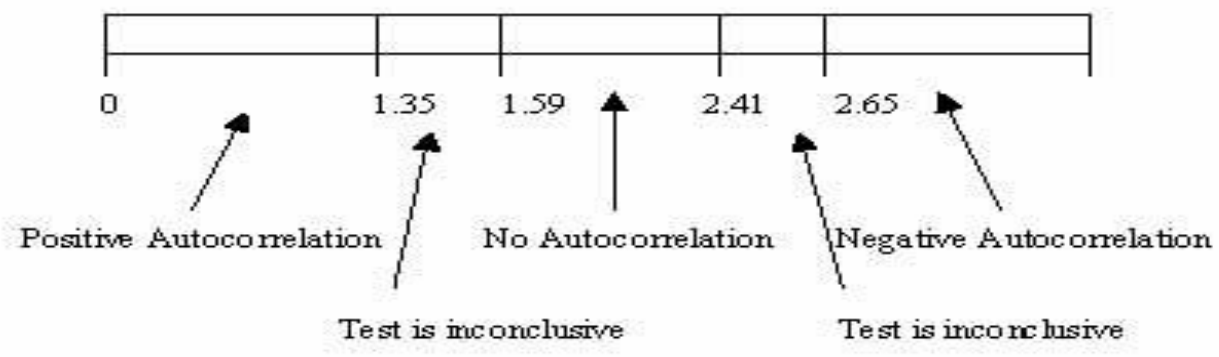

Sumber: Gujarati, Damodar N, (1999)

Berdasarkan hasil uji autokorelasi, nilai durbin-waston yang diperoleh sebesar 1,844.

Dimana, nilai ini berada pada daerah yang tidak terdapat autokorelasi (tabel 4.1) atau daerah ktitis durbin-waston. Oleh sebab itu, dapat dinyatakan bahwa data yang berasal dari variabel bebas tidak terdapat autokorelasi. 


\section{Deskripsi Variabel}

Jumlah pernyataan kuesioner adalah 19, terdiri dari 6 butir untuk variabel X1, 3 butir untuk variabel X2, 5 butir untuk variabel $\mathrm{X} 3$, dan 5 butir untuk variabel $Y$. Hasil analisis deskriptif variabel adalah sebagai berikut:

Tabel 1.5 Analisis Deskriptif Variabel

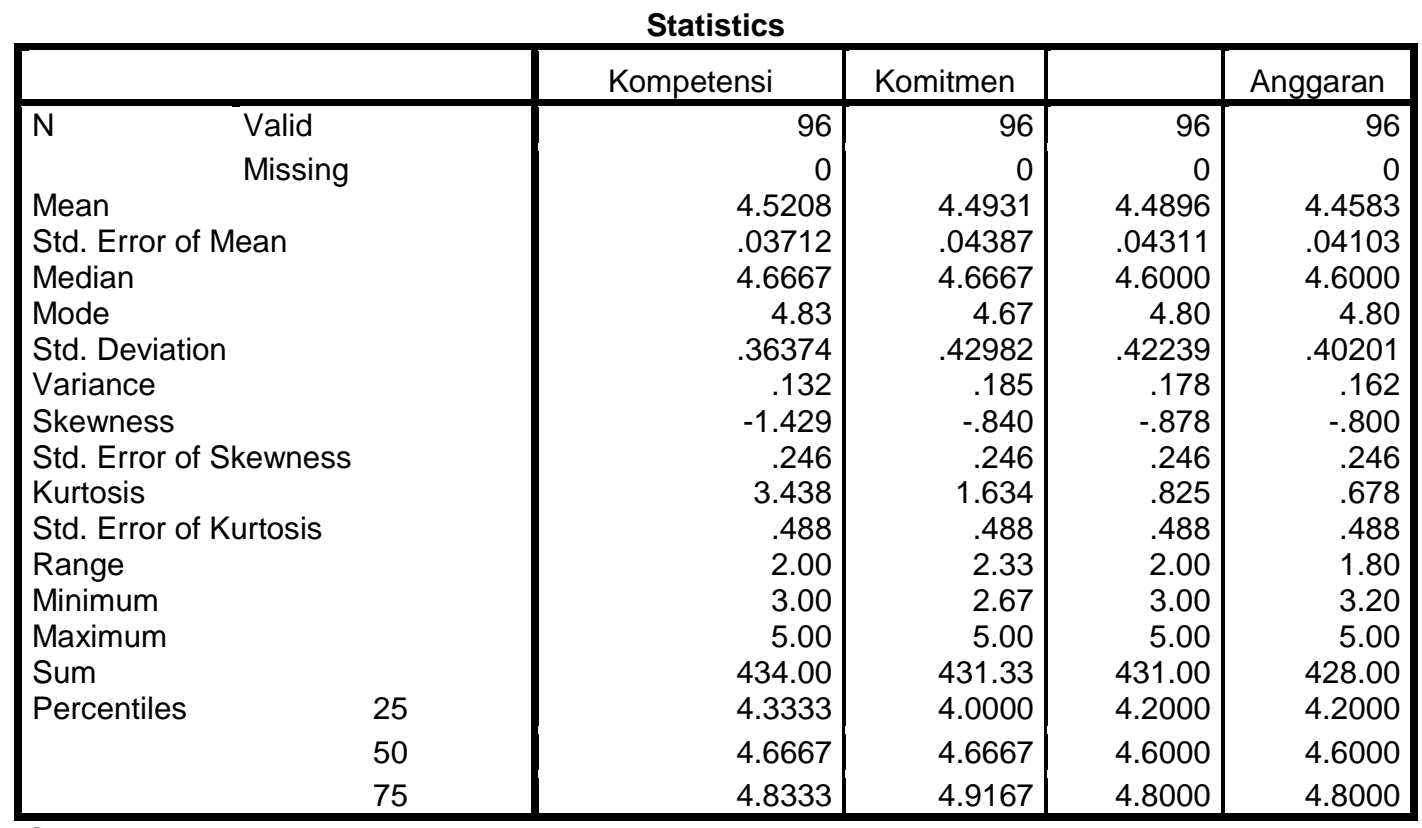

Sumber : Lampiran, diolah, 2019

Deskripsi tiap variabel dalam penelitian ini disajikan dalam bentuk frekuensi dan persentase jawaban responden beserta kriteria interpretasi rata-rata skor dalam lima tingkatan yaitu 1) sangat rendah (rata-rata 1.00-1.80), 2) rendah (rata-rata 1.81-2.60), 3) sedang (rata-rata 2.61-3.40), 4) tinggi (rata-rata 3.41-4.20), dan sangat tinggi (rata-rata 4.21$5.00)$.

a. Deskripsi Variabel Kompetensi (X1). Variabel kompetensi (X1) terdiri atas enam item pertanyaan. Hasil deskripsi jawaban terhadap variabel motivasi kerja secara lengkap disajikan pada tabel berikut ini :

Tabel 1.6 Jawaban Responden atas Variabel Kompetensi SDM (X1)

\begin{tabular}{|c|l|c|}
\hline $\begin{array}{c}\text { No } \\
\text { Item }\end{array}$ & \multicolumn{1}{|c|}{ Item Pertanyaan } & $\begin{array}{c}\text { Rata- } \\
\text { rata }\end{array}$ \\
\hline $\mathrm{X} 1.1$ & Apakah latar belakang pendidikan telah sesuai dengan bidang pekerjaan? & 4.69 \\
\hline $\mathrm{X} 1.2$ & Apakah mengetahui secara detail apa yang dikerjakan. & 4.57 \\
\hline
\end{tabular}




\begin{tabular}{|c|l|c|}
\hline $\begin{array}{c}\text { No } \\
\text { Item }\end{array}$ & \multicolumn{1}{|c|}{ Item Pertanyaan } & $\begin{array}{c}\text { Rata- } \\
\text { rata }\end{array}$ \\
\hline $\mathrm{X} 1.3$ & $\begin{array}{l}\text { Memutuskan sesuatu yang berkaitan dengan pekerjaan dan berani } \\
\text { bertanggungjawab atas keputusan tersebut. }\end{array}$ & 4.44 \\
\hline $\mathrm{X} 1.4$ & $\begin{array}{l}\text { Apakah pernah mengikuti pendidikan atau pelatihan yang berkaitan } \\
\text { dengan penyusunan anggaran? }\end{array}$ & 4.50 \\
\hline $\mathrm{X} 1.5$ & Apakah memiliki akses terhadap apa yang dikerjakan? & 4.46 \\
\hline $\mathrm{X} 1,6$ & Kebutuhan SDM yang sesuai dengan bidang pekerjaan mencukupi. & 4.43 \\
\hline \multicolumn{2}{|c|}{ Rata-rata dari rata-rata nilai Variabel Kompetensi SDM (X1) } & 4.52 \\
\hline
\end{tabular}

Sumber : Lampiran, diolah, 2019

Berdasarkan Tabel di atas, terlihat bahwa; nilai rata-rata untuk enam indikator dari varaibel Kompetensi berkisar dari 4,4375 sampai dengan 4,697917. Nilai ini berada pada kategori sangat setuju. Hal ini artinya responden memberikan pernyataan sangat setuju terhadap varaibel Kompetensi SDM dalam hubungannya dengan penentuan Anggaran Berbasis Kinerja.

b. Deskripsi Variabel Komitmen Organisasi (X2). Indikator Komitmen Organisasi yang digunakan dalam penelitian ini terdiri dari tiga indikator. Hasil deskripsi variabel Komitmen Organisasi secara lengkap disajikan pada tabel berikut ini.

Tabel 1.7 Jawaban Responden atas Variabel Komitmen Organisasi (X2)

\begin{tabular}{|c|l|c|}
\hline $\begin{array}{c}\text { No } \\
\text { Item }\end{array}$ & \multicolumn{1}{|c|}{ Item Pernyataan } & $\begin{array}{c}\text { Rata- } \\
\text { rata }\end{array}$ \\
\hline X2.1 & $\begin{array}{l}\text { Apakah Bapak/lbu/Saudara merasa senang dan bangga dengan } \\
\text { pekerjaan anda karena cocok dengan hati nurani anda? }\end{array}$ & 4.5 \\
\hline X2.2 & $\begin{array}{l}\text { Apakah Bapak/lbu/Saudara telah siap untuk segala resiko dan bekerja } \\
\text { dengan baik dan benar sesuai tujuan dan harapan instansi? }\end{array}$ & 4.54 \\
\hline X2.3 & $\begin{array}{l}\text { Apakah bapak/ibu/saudara benar-benar mencintai pekerjaan anda dan } \\
\text { bersedia mengabdikan diri demi tercapainya tujuan dan harapan instansi } \\
\text { tempat anda bekerja? }\end{array}$ & 4.43 \\
\hline & Rata-rata dari rata-rata nilai Variabel Komitmen Organisasi (X2) & 4.49 \\
\hline
\end{tabular}

Sumber : Lampiran, diolah, 2019

Berdasarkan Tabel di atas, terlihat bahwa, nilai rata-rata untuk ketiga indikator dari varaibel Komitmen Organisasi berkisar dari 4.4375 sampai dengan 4.54167. Nilai ini berada pada kategori sangat setuju. Hal ini artinya responden memberikan pernyataan sangat setuju 
terhadap varaibel Komitmen Organisasi yang ditunjukkan para pegawai saat ini dalam kaitannya dengan penyusunan Anggaran Berbasis Kinerja

c. Deskripsi Variabel Penghargaan (X3). Variabel ini terdiri atas lima item pernyataan. Hasil deskripsi variabel Penghargaan secara lengkap disajikan pada tabel berikut ini:

Tabel 1.8 Jawaban Responden atas Variabel Penghargaan (X3)

\begin{tabular}{|c|l|c|}
\hline $\begin{array}{c}\text { No. } \\
\text { Item }\end{array}$ & \multicolumn{1}{|c|}{ Item Pernyataan } & $\begin{array}{c}\text { Rata- } \\
\text { rata }\end{array}$ \\
\hline X3.1 & $\begin{array}{l}\text { Apakah bapak, Ibu, Saudara/i mendapat upah atas apa yang } \\
\text { dikerjakan? }\end{array}$ & 4.43 \\
\hline X3.2 & Apakah bapak/ibu/saudara memiliki gaji tetap selama bekerja? & 4.54 \\
\hline X3.3 & $\begin{array}{l}\text { Apakah bapak, Ibu, Saudara/i mendapatkan bonus ketika } \\
\text { menyelesaikan pekerjaan? }\end{array}$ & 4.52 \\
\hline X3.4 & $\begin{array}{l}\text { Apakah bapak, Ibu, Saudara/i menerima tunjangan tambahan sesuai } \\
\text { pekerjaan? }\end{array}$ & 4.51 \\
\hline X3.5 & Apakah bapak, Ibu, Saudara/i menerima penghargaan dalam bekerja? & 4.43 \\
\hline \multicolumn{2}{|c|}{ Rata-rata dari rata-rata Nilai Variabel Penghargaan (X3) } & 4.48 \\
\hline
\end{tabular}

Sumber : Lampiran, diolah, 2019

Berdasarkan Tabel di atas, terlihat bahwa; nilai rata-rata untuk lima indikator dari varaibel Penghargaan berkisar dari 4.4375 sampai dengan 4.54167. Nilai ini menunjukkan bahwa persepsi responden termasuk kedalam kategori sangat setuju terhadap variabel Penghargaan dalam hubungannya dengan penyusunan Anggaran Berbasis Kinerja.

d. Deskripsi Variabel Anggaran Berbasis Kinerja

Tabel 1.9 Jawaban Responden atas Variabel Anggaran Berbasis Kinerja (Y)

\begin{tabular}{|c|l|c|}
\hline $\begin{array}{c}\text { No. } \\
\text { Item }\end{array}$ & \multicolumn{1}{|c|}{ Item Pernyataan } & $\begin{array}{c}\text { Rata- } \\
\text { rata }\end{array}$ \\
\hline Y1 & Apakah Bapak/lbu/Saudara berkontribusi dalam penyusunan anggaran? & 4.44 \\
\hline Y2 & Apakah bapak/ibu/saudara terlibat dalam penyusunan anggaran? & 4.52 \\
\hline Y3 & Apakah ada alasan yang jelas dalam melakukan revisi anggaran? & 4.43 \\
\hline Y4 & $\begin{array}{l}\text { Apakah Bapak/lbu/Saudara memiliki usulan kepada atasan terkait } \\
\text { penyusunan anggaran? }\end{array}$ & 4.47 \\
\hline Y5 & $\begin{array}{l}\text { Apakah Bapak/lbu/Saudara dalam penyelesaian penyusunan anggaran } \\
\text { meminta pendapat kepada atasan/pimpinan? }\end{array}$ & 4.40 \\
\hline & Rata-rata dari rata-rata Nilai Variabel Anggaran Berbasis Kinerja (Y) & 4.45 \\
\hline
\end{tabular}




\section{Sumber : Lampiran, diolah, 2019}

Dari tabel di atas, terlihat bahwa nilai rata-rata untuk kelima indikator dari varaibel Anggaran Berbasisi Kinerja berkisar antara 4,40625 sampai dengan 4.520833. Nilai rata-rata tersebut berada pada kategori sangat setuju. Hal ini berarti bahwa responden memberikan pernyataan sangat setuju terhadap varaibel Anggaran Berbasisi Kinerja sebagai variabel independen.

\section{Analisis Regresi Berganda}

Tabel 1.10 Hasil Analisis Regresi Berganda

\begin{tabular}{|c|c|c|c|c|c|c|}
\hline \multicolumn{7}{|c|}{ Coefficients $^{a}$} \\
\hline \multirow{2}{*}{\multicolumn{2}{|c|}{ Model }} & \multicolumn{2}{|c|}{ Unstandardized Coefficients } & \multirow{2}{*}{$\begin{array}{c}\text { Standardized } \\
\text { Coefficients } \\
\text { Beta }\end{array}$} & \multirow[b]{2}{*}{$\mathrm{t}$} & \multirow[b]{2}{*}{ Sig. } \\
\hline & & $B$ & Std. Error & & & \\
\hline \multirow[t]{4}{*}{1} & (Constant) & 11.412 & 2.890 & & 3.949 & .000 \\
\hline & Kompetensi & .074 & .094 & .081 & .787 & .433 \\
\hline & Komitmen & .062 & .159 & .040 & .392 & .696 \\
\hline & Penghargaan & .358 & .099 & .376 & 3.595 & .001 \\
\hline
\end{tabular}

a. Dependent Variable: Anggaran

Sumber : Lampiran, diolah, 2019

Persamaan regresi linier berganda dalam penelitian ini adalah :

$\mathrm{Y}=\mathrm{b} 0+\mathrm{b} 1 \mathrm{X} 1+\mathrm{b} 2 \mathrm{X} 2+\mathrm{b} 3 \mathrm{X} 3+\mathrm{e}$

$Y=11.412+0.074 X 1+(0.062) X 2-0.358 X 3$

Dimana :

$$
\begin{array}{ll}
\mathrm{Y} & =\text { Anggaran Berbasis Kinerja } \\
\mathrm{bo} & =\text { Konstanta } \\
\mathrm{b} & =\text { Slope atau Koefisien Regresi } \\
\mathrm{X} 1 & =\text { Kompetensi SDM } \\
\mathrm{X} 2 & =\text { Komitmen Organisasi } \\
\mathrm{X} 3 & =\text { Penghargaan } \\
\mathrm{e} & =\text { faktor gangguan atau kesalahan }
\end{array}
$$

Persamaan regresi linier berganda memiliki uraian sebagai berikut:

$\beta 1=0.074$; yang artinya, apabila variabel Kompetensi SDM meningkat, maka terjadi perubahan yang positif pula pada Anggaran Berbasis Kinerja (Variabel bebas konstan). 
$\beta 2=0.062$; yang artinya, apabila Komitmen Organisasi meningkat, maka akan menyebabkan perubahan positif pada Anggaran Berbasis Kinerja (Variabel bebas konstan).

$\beta 3=0.358$; yang artinya, apabila variabel Penghargaan meningkat, maka mengakibatkan perubahan positif pada Anggaran Berbasis Kinerja (Variabel bebas konstan).

\section{Pengujian Hipotesis}

\section{Pengujian Secara Parsial (Uji T)}

Uji t yaitu dengan membandingkan $t$ hitung dengan $t$ tabel (thitung $>$ ttabel) atau probabilitas nilai signifikan dibandingkan dengan alpha yang digunakan dalam penelitian yaitu $5 \%$ atau 0,05 . Hasil uji t dengan menggunakan program SPSS.

Tabel 1.11 Hasil Analisis Uji T Variabel Bebas (X1, X2, dan X3)

\begin{tabular}{|c|c|c|c|c|c|c|}
\hline \multicolumn{7}{|c|}{ Coefficients $^{a}$} \\
\hline \multirow{2}{*}{\multicolumn{2}{|c|}{ Model }} & \multicolumn{2}{|c|}{ Unstandardized Coefficients } & \multirow{2}{*}{$\begin{array}{c}\begin{array}{c}\text { Standardized } \\
\text { Coefficients }\end{array} \\
\text { Beta }\end{array}$} & \multirow[b]{2}{*}{$\mathrm{t}$} & \multirow[b]{2}{*}{ Sig. } \\
\hline & & $\mathrm{B}$ & Std. Error & & & \\
\hline \multirow[t]{2}{*}{1} & (Constant) & 3.337 & .504 & & 6.624 & .000 \\
\hline & KSDM & .248 & .111 & .224 & 2.232 & .028 \\
\hline
\end{tabular}

a. Dependent Variable: ABK

\section{Coefficients $^{\mathrm{a}}$}

\begin{tabular}{|c|c|c|c|c|c|c|}
\hline \multirow{2}{*}{\multicolumn{2}{|c|}{ Model }} & \multicolumn{2}{|c|}{ Unstandardized Coefficients } & \multirow{2}{*}{$\begin{array}{c}\text { Standardized } \\
\text { Coefficients } \\
\text { Beta }\end{array}$} & \multirow[b]{2}{*}{$\mathrm{t}$} & \multirow[b]{2}{*}{ Sig. } \\
\hline & & $\mathrm{B}$ & Std. Error & & & \\
\hline \multirow[t]{2}{*}{1} & (Constant) & 3.663 & .428 & & 8.568 & .000 \\
\hline & $\mathrm{KO}$ & .177 & .095 & .189 & 1.868 & .065 \\
\hline
\end{tabular}

a. Dependent Variable: ABK

Coefficients $^{\mathrm{a}}$

\begin{tabular}{|c|c|c|c|c|c|c|}
\hline \multirow{2}{*}{\multicolumn{2}{|c|}{ Model }} & \multicolumn{2}{|c|}{ Unstandardized Coefficients } & \multirow{2}{*}{$\begin{array}{c}\begin{array}{c}\text { Standardized } \\
\text { Coefficients }\end{array} \\
\text { Beta }\end{array}$} & \multirow[b]{2}{*}{$\mathrm{t}$} & \multirow[b]{2}{*}{ Sig. } \\
\hline & & $\mathrm{B}$ & Std. Error & & & \\
\hline \multirow[t]{2}{*}{1} & (Constant) & 2.673 & .402 & & 6.647 & .000 \\
\hline & PR & .398 & .089 & .418 & 4.457 & .000 \\
\hline
\end{tabular}

a. Dependent Variable: $A B K$ 
Sumber : Lampiran, diolah, 2019

Berdasarkan hasil pengujian secara parsial yang ditampilkan pada tabel 4.11, maka dapat dijelaskan bahwa nilai $t$ hitung untuk variabel $\mathrm{X} 1, \mathrm{X} 2$, dan $\mathrm{X} 3$ adalah sebesar 2.232 (X1), 1.868 (X2), dan 4.457 (X3). Sementara itu, nilai t tabel (Dari sumber tabel t) adalah sebesar 1.98609. Dengan demikian, karena nilai t hitung $\mathrm{X} 1$ dan $\mathrm{X} 3>t$ tabel, maka dapat disimpulkan bahwa variabel bebas (X1 dan X3) yaitu: Kompetensi SDM dan Penghargaan berpengaruh signifikan terhadap penyusunan Anggaran Berbasis Kinerja. Sedangkan variabel bebas Komitmen Organisasi (X2) tidak berpengaruh terhadap penyusunan Anggaran Berbasis Kinerja karena nilainya $<$ t tabel.

\section{Pengujian Secara Simultan (Uji F)}

Pembuktian terhadap hipotesis I dijawab dengan menggunakan uji $F$, yaitu untuk mengetahui sejauh mana variabel-variabel bebas yang digunakan mampu menjelaskan variabel terikatnya. Tabel 1.12 Hasil Analisis Uji F
ANOVA $^{\mathrm{b}}$

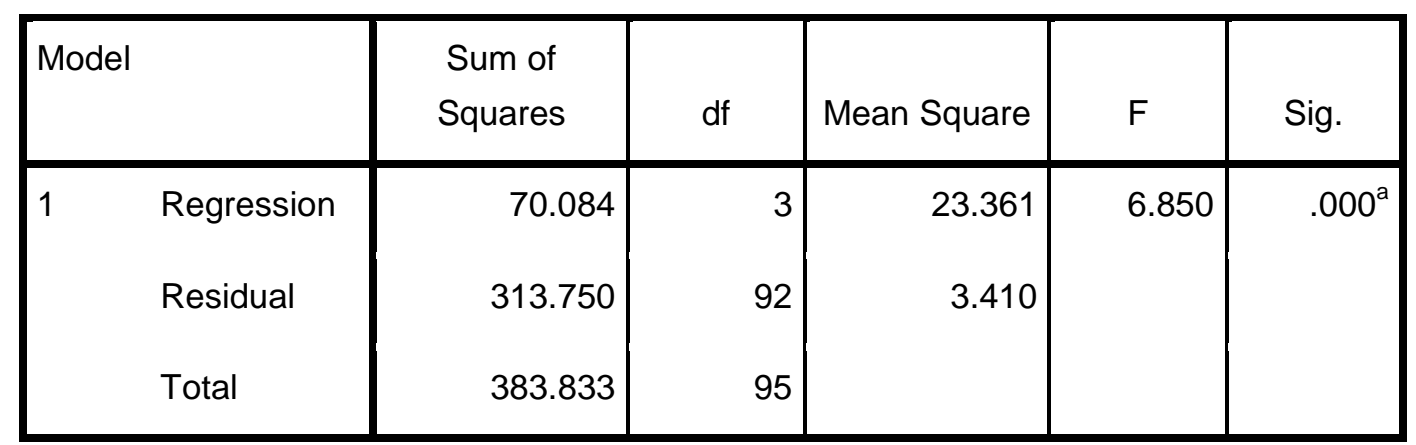

a. Predictors: (Constant),Penghargaan , Komitmen, Kompetensi

b. Dependent Variable: Anggaran

Sumber : Lampiran, diolah, 2019

Berdasarkan tabel di atas nilai $f_{\text {hitung }}$ adalah sebesar 6.850 dan nilai Sig. 0.000. Sedangkan nilai $f_{\text {tabel }}$ adalah 2.70. Dari hasil perhitungan tersebut kemudian dibandingkan dengan nilai $f_{\text {tabel }}$ sehingga diperoleh hasil bahwa nilai $f_{\text {hitung }}>f_{\text {tabel }}(6.850>2.70)$ dan nilai Sig. $(0.000)<0.05$, berdasarkan hasil perbandingan ini maka dapat dijelaskan bahwa variabel bebas X1 (Kompetensi SDM), X2 (Komitmen Organisasi), dan X3 (Penghargaan) 
secara bersama-sama (simultan) berpengaruh terhadap penyusunan Anggaran Berbasis Kinerja di lingkungan Pemerintah Daerah Provinsi Papua Barat. Dengan demikian $\mathrm{H}_{\mathrm{o}}$ ditolak dan $\mathrm{H}_{\mathrm{a}}$ diterima.

\section{Koefisien Determinasi}

Pengujian koefisien determinasi dibutuhkan untuk menentukan varaibel bebas manakah yang paling dominan berpengaruh terhadap variabel terikat. Pada penelitian ini nilai Sig. hitung akan dibandingkan dengan tingkat signifikan (a) $=5 \%$. Selanjutnya, $R$ square maupun nilai korelasi masing-masing variabel bebas akan digunakan untuk menghitung nilai kontribusinya terhadap variabel terikat.

Tabel 1.13 Hasil Analisis Koefisien Determinasi

Model Summary

\begin{tabular}{|c|c|c|c|c|}
\hline Model & $\mathrm{R}$ & $\mathrm{R}$ Square & $\begin{array}{c}\text { Adjusted R } \\
\text { Square }\end{array}$ & $\begin{array}{c}\text { Std. Error of the } \\
\text { Estimate }\end{array}$ \\
\hline 1 & $.427^{\mathrm{a}}$ & .183 & .156 & 1.84671 \\
\hline
\end{tabular}

a. Predictors: (Constant),Penghargaan , Komitmen, Kompetensi

b. Dependent Variable: Anggaran

Sumber : Lampiran, diolah, 2019

Dari tabel di atas dapat ditentukan bahwa koefisien determinasi atau kontribusi dari ketiga variabel bebas terhadap variabel terikat adalah sebesar $0.183(18.3 \%)$. Nilai tersebut mengartikan bahwa variabel bebas (Kompetensi SDM, Komitmen Organisasi, dan Penghargaan) hanya memberikan pengaruh sebesar $18.3 \%$ terhadap variabel terikat. Sedangkan sisanya $81.7 \%(100 \%-18.3 \%)$ dipengaruhi oleh faktor lain (yang tidak diteliti) diluar persamaan regresi yang digunakan.

Berdasarkan hasil perhitungan kontribusi masing-masing variable bebas, dapat dijelaskan bahwa variabel yang paling berpengaruh dominan terhadap penyusunan Anggaran Berbasis Kinerja adalah Penghargaan. 


\section{Pembahasan}

\section{Pengaruh Variabel Bebas Secara Parsial Terhadap Variabel Terikat}

\section{a. Pengaruh Kompetensi SDM terhadap Anggaran Berbasis Kinerja}

Hasil pengujian menunjukkan bahwa Kompetensi SDM secara parsial berpengaruh terhadap penyusunan Anggaran Berbasis Kinerja. Hasil tersebut juga menjelaskan bahwa semakin tinggi tingkat Kompetensi SDM di lingkungan Provinsi Papua Barat, maka secara otomatis berpengaruh dalam meningkatnya proses penyusunan Anggaran Berbasis Kinerja.

Hasil penelitian ini sejalan dengan penelitian yang dilakukan oleh Nawastri 2015 yang menyatakan bahwa kompetensi sumber daya manusia berpengaruh positif dan signifikan terhadap anggaran berbasis kinerja. Dalam penelitian yang dilakukan oleh Norhayati et al., 2013, ditemukan juga bahwa kompetensi berpengaruh positif dan signifkan terhadap anggaran berbasis kinerja. Sumber daya manusia mempengaruhi rencana kerja anggaran organisasi, serta merupakan pilar penyangga utama dan penggerak roda organisasi dalam mewujudkan visi dan misi serta tujuan dari organisasi. Oleh karena itu, melalui sumber daya manusia yang efektif dalam hal penempatan tugas, pelatihan, partisipasi, penilaian kinerja, dan kompensasi dapat meningkatkan kemampuan mereka untuk mencapai tujuan organisasi Delanno \& Deviani, 2013 Pengaruh Komitmen Organisasi terhadap Anggaran Berbasis Kinerja

Hasil pengujian menunjukkan bahwa secara parsial komitmen organisasi tidak berpengaruh terhadap penyusunan anggaran berbasis kinerja di lingkungan Pemerintah Daerah Provinsi Papua Barat. Hasil ini menunjukkan bahwa walau semakin baik komitmen organisasi, tidak serta merta berarti meningkatkan kualitas anggaran berbasis kinerja. Hasil ini didukung oleh penelitian Pramitadari, (2016) bahwa komitmen organisasi tidak berpengaruh signifikan terhadap penyusunan Anggaran berbasis kinerja. Hasil penelitian serupa juga diperoleh Syarifah Massuki Fitri, (2013), dimana mereka menemukan bahwa komitmen organisasi tidak berpengaruh terhadap anggaran berbasis kinerja. 
Komitmen organisasi memberikan dorongan dari dalam individu untuk berbuat sesuatu agar dapat menunjang keberhasilan organisasi sesuai dengan tujuan dan lebih mengutamakan kepentingan organisasi dibandingkan dengan kepentingan sendiri. Karyawan dengan komitmen yang tinggi diharapkan dapat memperlihatkan kinerja yang optimal. Komitmen organisasi diartikan sebagai suatu ikatan psikologis karyawan pada organisasi, yang akan memberikan dampak secara langsung terhadap tujuan organisasi Sopiah, (2008).

\section{b. Pengaruh Penghargaan terhadap Anggaran Berbasis Kinerja}

Berdasarkan hasil penelitian diperoleh bahwa pemberian penghargaan sangat berpengaruh secara parsial terhadap penyusunan anggaran berbasis kinerja di lingkungan Pemerintah Daerah Provinsi Papua Barat. Hal ini berarti bahwa pemberian penghargaan merupakan faktor utama yang mempengaruhi kualitas penyusunan anggaran berbasis kinerja.

Hasil penelitian ini sesuai dengan yang dilakukan oleh Norhayati et al., (2013) yang menyatakan bahwa penghargaan berpengaruh positif dan signifikan terhadap anggaran berbasis kinerja pada pemerintahan kabupaten Lombok Barat. Hasil penelitian ini juga sejalan dengan penelitian yang dilakukan oleh Izzaty, (2011) dan Arifah, (2012) yang menemukan bahwa terdapat pengaruh positif dan signifikan secara parsial dari variabel penghargaan terhadap anggaran berbasis kinerja.

Tingginya pengaruh pemberian penghargaan terhadap penyusunan anggaran berbasis kinerja disebabkan karena pada dasarnya sistem penghargaan dan atau pengakuan atas kinerja karyawan merupakan sarana untuk mengarahkan perilaku karyawan (pegawai) ke perilaku yang dihargai dan diakui organisasi. Sehingga hal tersebut menjadi motivasi lebih bagi aparat pemerintah (individu) dalam meningkatkan kinerja mereka, yang secara tidak langsung berkorelasi pada meningkatnya kualitas penyusunan anggaran berbasis kinerja. 


\section{Pengaruh Variabel Bebas Secara Simultan Terhadap Variabel Terikat}

\section{a. Pengaruh Kompetensi SDM, Komitmen Organisasi, dan Penghargaan terhadap}

\section{Anggaran Berbasis Kinerja}

Berdasarkan hasil pengujian hipotesis dapat dijelaskan bahwa kompetensi SDM, komitmen organisasi, dan pemberian penghargaan secara bersama-sama terbukti berpengaruh signifikan terhadap penyusunan anggaran berbasis kinerja di lingkungan Pemerintah Daerah Provinsi Papua Barat. Hubungan positif yang signifikan ini memilik arti bahwa penyusunan anggaran berbasis kinerja akan bertambah baik jika kompetensi SDA, komitmen organisasi, dan pemberian penghargaan bertambah baik pula.

Hasil penelitian ini sejalan dengan penelitian yang dilakukan oleh Diastuti \& Aris, (2017) yang menyatakan bahwa kompetensi sumber daya manusia, komitmen organisasi, dan penghargaan berpengaruh terhadap penerapan anggaran berbasis kinerja.

\section{b. Variabel Yang Dominan Berpengaruh Terhadap Anggaran Berbasis Kinerja}

Hasil pengujian koefisien determiasi menunjukkan bahwa variabel Penghargaan memberikan kontribusi terbesar dalam meningkatkan penyusunan anggaran berbasis kinerja di lingkungan Pemerintah Daerah Provinsi Papua Barat. Hal ini berarti bahwa, meskipun secara simultan ketiga variabel bebas berpengaruh terhadap penyusunan anggaran berbasis kinerja sebagai variabel terikat, akan tetapi kontribusi terbesar diberikan oleh adanya pemberian penghargaan. Sementara itu, karena nilai kontribusi variabel kompetensi SDA dan komitmen organisasi terbilang kecil, maka dalam penelitian ini dapat dinyatakan bahwa hanya pemberian penghargaanlah yang berpengaruh terhadap penyusunan anggaran berbasis kinerja.

Hasil kuesioner dapat dijelaskan juga bahwa pada kenyataannya variabel penghargaan dianggap sebagai sesuatu yang sangat berperan penting dalam mempengaruhi perilaku dan lingkungan kerja para staf di Pemda Provinsi Papua Barat, sehingga bagi mereka (pegawai) hal tersebut secara langsung memberikan dampak 
terhadap kinerja mereka. Hasil penelitian ini secara jelas menunjukkan bahwa pemberian penghargaan dan kompetensi SDM memiliki peranan yang positif dalam proses penyusunan anggaran berbasis kinerja. Selain itu, dari hasil penelitian ini dapat dinyatakan pula bahwa para responden menempatkan penghargaan sebagai hal yang jauh lebih penting dibandingkan kompetensi SDM maupun komitmen organisasi. Meskipun memberikan pengaruh positif terhadap penyusunan anggaran berbasis kinerja, namun kondisi tersebut (pemberian penghargaan) bukanlah faktor utama yang harus tetap dipertahankan untuk meningkatkan atau memotivasi pegawai dalam bekerja (menyusun anggaran berbasis kinerja), mengingat praktek pemberian penghargaan tidak selamanya dapat diterapkan dalam sistem pemerintahan.

Oleh sebab itu, sebagai bahan pertimbangan bagi satuan kerja di lingkungan Pemda Provinsi Papua Barat agar lebih memperhatikan kompetensi SDM maupun komitmen organisasi sebagai faktor utama yang berperan penting untuk memotivasi diri dalam menyusun anggaran berbasis kinerja. Kedua faktor tersebut (kompetensi SDM dan komitmen organisasi) dipandang penting karena memiliki dampak yang jauh lebih luas dalam satuan kerja (seluruh anggota/pegawai) dan secara hirarki lebih bersifat mengikat individu (pegawai) untuk lebih mencintai dan bertanggungjawab terhadap pekerjaannya dibandingkan dengan memberi penghargaan.

\section{KESIMPULAN}

1. Secara parsial variabel bebas (kompetensi SDM dan penghargaan) memberikan pengaruh terhadap penyusunan anggaran berbasis kinerja di lingkungan Pemerintah Daerah Provinsi Papua Barat.

2. Variabel kompetensi SDM, komitmen organisasi dan penghargaan secara simultan atau bersama-sama memberikan pengaruh terhadap penyusunan anggaran berbasis kinerja di lingkungan Pemerintah Daerah Provinsi Papua Barat.

3. Variabel yang paling dominan berpengaruh terhadap penyusunan anggaran berbasis kinerja di lingkungan Pemerintah Daerah Provinsi Papua Barat adalah penghargaan. 


\section{DAFTAR PUSTAKA}

Arifah, D. A. (2012). Praktek Teori Agensi pada Entitas Publik dan Non Publik. PRESTASI, 9(01).

Asikin, M., \& Junaedi, I. (2013). Kemampuan komunikasi matematika siswa SMP dalam setting pembelajaran RME (Realistic Mathematics Education). Unnes Journal of Mathematics Education Research, 2(1).

Delanno, G. F., \& Deviani, D. (2013). Pengaruh Kapasitas SDM, Pemanfaatan TI Dan Pengawasan Keuangan Terhadap Nilai Informasi Pelaporan Keuangan Pemerintah Daerah. Wahana Riset Akuntansi, 1(1), 21-46.

Diastuti, P., \& Aris, M. A. (2017). Analisis Faktor-Faktor Yang Mempengaruhi Penerapan Anggaran Berbasis Kinerja (Studi Pada Organisasi Perangkat Daerah Kabupaten Boyolali). Universitas Muhammadiyah Surakarta.

Djati, S. P., \& Darmawan, D. (2004). Pengaruh kesan kualitas layanan, harga, dan kepuasan mahasiswa PTS terhadap minat mereferensikan kampusnya. Widya Journal of Management and Accounting, 4(2), 220126.

Fitri, A. S. (2013). Hubungan Dukungan Keluarga Dengan Penatalaksanaan Nyeri Pada Penderita Artritis Rheumatoid Di Wilayah Kerja Puskesmas Andalas Padang Tahun 2013. Universitas Andalas.

Iqsan. (2016). The Mandatory Designation Of A Data Protection Officer In Indonesia's Upcoming Personal Data Protection Law.

Irmayanti, G. (2013). Analisis Perilaku Investor Surabaya Dalam Alokasi Aset Investasinya Menggunakan Analytical Hierarchy Process (Ahp). Universitas Airlangga.

Kusumaputri. (2015). (Institute of Electrical Machines, RWTH Aachen University, Aachen, Germany). Roman Konrad (Institute of Electrical Machines, RWTH Aachen University, Aachen, Germany).

Li, C., lqbal, M., Lin, J., Luo, X., Jiang, B., Malgras, V., ... Yamauchi, Y. (2018). Electrochemical deposition: an advanced approach for templated synthesis of nanoporous metal architectures. Accounts of Chemical Research, 51(8), 1764-1773.

Linkie, M., Dinata, Y., Nugroho, A., \& Haidir, I. A. (2007). Estimating occupancy of a data deficient mammalian species living in tropical rainforests: sun bears in the Kerinci Seblat region, Sumatra. Biological Conservation, 137(1), 20-27.

Mappeasse, M. Y. (2009). Pengaruh cara dan motivasi belajar terhadap hasil belajar programmable logic controller (PLC) siswa kelas III jurusan listrik SMK Negeri 5 Makassar. Jurnal Medtek, 1(2), 1-6.

Muhandri, T., \& Kadarisman, D. (2012). Sistem Jaminan Mutu Industri Pangan. PT Penerbit IPB Press.

Nawastri, S., \& Rohman, A. (2015). Analisis Faktor-Faktor yang Berpengaruh Terhadap Efektivitas Penerapan Anggaran Berbasis Kinerja (Studi Kasus Pada SKPD Pemerintah Kabupaten Grobogan). Fakultas Ekonomika dan Bisnis.

Norhayati, I., Getha, K., Haffiz, J. M., Ilham, A. M., Sahira, H. L., Syarifah, M. M. S., \& Syamil, A. M. (2013). In vitro antitrypanosomal activity of Malaysian plants. Journal of Tropical Forest Science, 52-59.

Nur Izzaty, K., \& ABDUL ROHMAN, A. R. (2011). Pengaruh Gaya Kepemimpinan Dan Kualitas Sumber Daya Manusia Terhadap Penerapan Anggaran Berbasis Kinerja Badan 
Layanan Umum (Studi pada BLU Universitas Diponegoro Semarang). Universitas Diponegoro.

Pramitadari, A. (2016). Pengaruh komitmen organisasi, sistem administrasi, dan sumber daya manusia terhadap penyusunan anggaran berbasis kinerja pada pemerintah daerah Kabupaten Bangka Barat. Universitas Bangka Belitung.

Premeaux, S. R., \& Mondy, R. W. (1993). Linking management behavior to ethical philosophy. Journal of Business Ethics, 12(5), 349-357.

Prince, M. J., Wu, F., Guo, Y., Robledo, L. M. G., O'Donnell, M., Sullivan, R., \& Yusuf, S. (2015). The burden of disease in older people and implications for health policy and practice. The Lancet, 385(9967), 549-562.

Robbins, S. P. (n.d.). Dan Timothy A. Judge. 2008. Perilaku Organisasi.

Sarungallo, Z. L., Hariyadi, P., Andarwulan, N., Purnomo, E. H., \& Wada, M. (2015). Analysis of $\alpha$-cryptoxanthin, $\beta$-cryptoxanthin, $\alpha$-carotene, and $\beta$-carotene of Pandanus conoideus oil by high-performance liquid chromatography (HPLC). Procedia Food Science, 3, 231243.

Simamora, P., Alvarez, J. M., \& Yalkowsky, S. H. (2001). Solubilization of rapamycin. International Journal of Pharmaceutics, 213(1-2), 25-29.

Sopiah, S. (2008). Budaya Organisasi, Komitmen Organisasional Pimpinan Dan Pengaruhnya Terhadap Kepuasan Kerja Dan Kinerja Karyawan Bank. Jurnal Keuangan Dan Perbankan, 12(2), 308-317.

Sugiyono, A. (2004). Perubahan paradigma kebijakan energi menuju pembangunan yang berkelanjutan. In Dipresentasikan pada Seminar Akademik Tahunan Ekonomi I, Pascasarjana FEUI \& ISEI (pp. 8-9).

Suka, I. G., Simanjuntak, W., Sembiring, S., \& Trisnawati, E. (2009). Karakteristik Silika Sekam Padi dari Provinsi Lampung yang Diperoleh dengan Metoda Ekstraksi. MIPA Dan Pembelajarannya, 37(1).

Sutrisno, E., Oh, H., Vasan, A. S. S., \& Pecht, M. (2012). Estimation of remaining useful life of ball bearings using data driven methodologies. In 2012 ieee conference on prognostics and health management (pp. 1-7). IEEE.

Verya, E., Indrawati, N., \& Hanif, R. A. (2017). Analisis Pengaruh Ukuran Perusahaan, Leverage Dan Good Corporate Governance Terhadap Integritas Laporan Keuangan (Studi Empiris Pada Perusahaan Manufaktur Yang Listing Di Bursa Efek Indonesia Periode Tahun 2012-2014). Riau University.

Vosko, L. F., MacDonald, M., \& Campbell, I. (2009). Gender and the contours of precarious employment (Vol. 8). Routledge.

Wibowo, E. S., \& Syaichu, M. (2013). Analisis pengaruh suku bunga, inflasi, car, bopo, npf terhadap profitabilitas bank syariah. Diponegoro Journal of Management, 2(2), 10-19. 